\title{
Hybrid language of in-cockpit specialist discourse
}

\author{
Olena PETRASHCHUK \\ Uniwersytet Warszawski/ University of Warsaw \\ E-mail: o.petrashchuk@uw.edu.pl,
}

\begin{abstract}
The importance of communication in the cockpit is discussed, and the discourse analysis of a sample authentic in-cockpit communication during flight operation is presented. The analysis results indicate that specific language use variables are correlated with individual performance at the point of flight performance and individual communicative intentions. Also, language use was found to vary as a function of crew position, out-of-cockpit addressee and level of workload during the flight. Language use for the procedure purpose was tightly linked to cockpit panel readings, whereas language use for personal interaction was of 'over a cup of tea talk' pattern. These observations suggested a specific hybridness of the cockpit language discourse which might need to be further checked by an alternative research method of communication analysis., e.g., a content-coding method.
\end{abstract}

Key words: specialist discourse, in-cockpit communication, hybrid language, aviation English

\section{Statement of purpose}

The radiotelephony communication has specific characteristics, the most important and unique of which are non-visual language contact and strong safety focus, which requires full understanding of the message sent via radio from air to ground.

However, in real cockpit communication the scope of conversational exchanges is not limited by radiotelephony between a pilot and a controller. It also includes communication between members of the flight crew as well as between crewmembers and out-of-cockpit addressees like cabin crew and passengers.

The importance of in-cockpit language communication studies, on the one hand, becomes evident on the ground of a strong focus on flight safety where the language related human factor may play a contributing role. There were a few researches focusing particularly on radiotelephony discourse (O. Petrashchuk 2017), radiotelephony lexical corpus (S. Lopez et al. 2015), communicative functions of radiotelephony exchanges (J. Mell/ C. Godmet 2002) and others. On the other hand, the language communication in the cockpit has not been studied in discursive paradigm on a wide scale. Also there is no studies related to the role of readings from a flightdeck panel as a main non-verbal component of both in-voice only specialist ground-to-air exchanges and side-by-side in-cockpit interaction between crewmembers, correlation between a particular language used and a communication setting. 
It is a known fact, that the oral language discourse of radiotelephony is characterized by simultaneous use of two 'Englishes' - technical English, presented mostly by English phraseology, and plain English.

The technical English is composed of terms (phraseology) used during the flight operation and traffic control, whereas plain English has to be used when phraseology is not enough to complete the communicative intention. From this perspective, the plain English has a compensatory function within the terminological domain and, thus, should have the features of terms.

From this perspective, aviation English phraseology is defined as the specialised language used by pilots and controllers to conduct what is intended to be unambiguous and effective radiotelephony communications (i.e., flight operation safety). It is based on linguistic norms aimed to create less ambiguous communication thanks to simplified rules at a syntactic, lexical and semantic level. The linguistic normalisation also enables the various interlocutors to minimise their linguistic and cognitive efforts in carrying out the task at hand thanks to their shared [specialist] knowledge.

It is suggested, that specialist language used in radiotelephony has characteristics, which make it unique among other specialist languages because of: (a) being invented by a group of people; (b) based on strict rules of usage not to English grammar and phonology; (c) both message encoding and decoding not possible without special competence; (d) based on invalid routine syntax, semantics and pragmatics due to restricted register; (e) having high level of cultural sensitivity and probability of native language interferences; (f) communicative functions are specific for each interactant and rarely interchangeable.

The plain English is in fact a general English simplified for the purpose of aviation context. It is interesting, that International Civil Aviation Organization (ICAO) has stated that plain English should not be considered as natural language, since it is supposed to comply with phraseology's standards: "Plain language in aeronautical radiotelephony communications means the spontaneous, creative and non-coded use of a given natural language, although constrained by the functions and topics (aviation and non-aviation) that are required by aeronautical radiotelephony communications, as well as by specific safety-critical requirements for intelligibility, directness, appropriacy, nonambiguity and concision" (ICAO Doc 9835, 2010: 3.3.14).

Taking into account contextuality of in-cockpit communication, the initial source of a specialist discourse seems to be a context, which makes plain words similar to terms comprehensible by specialists. For example, to plain words - 'air' and 'born' create a term "airborne", which means a time point of taking off. The question 'Is flight level 270 available?' consists of plain words, but in the context of radiotelephony exchange it can have terminological meaning of a preferable cruise level. The phrase "I read you 5" might seem even ungrammatical if heard by a nonspecialist. In the radiotelephony context, it will mean perfect quality of a message received via radio. Collocation "information Mike" consists of a plain word and a personal name, but it has a special meaning related to meteorological information, transmitted on radio frequency and comprehensible by aviation specialists shared the same special knowledge. 
It is obvious that the in-cockpit communication discourse should be studied within the settings occurred in the cockpit, which are suggested to refer to language use and, therefore, code switching, communication intents/functions, verbal and non-verbal components of interaction. The discursive paradigm of in-cockpit communication with a strong focus on safety explains the role of language related human factor as part of complex techno-human architecture of flight safety.

Considering the coded register of aviation language as well as time limits during the flight, it can be assumed, that specific language discourse patterns can sufficiently vary during the short time periods from the natural language to interact with other people to highly technical language to cope with the professional task. The discourse should be contextual due to obvious correlation with the stages of the flight performance.

Taking into account contextuality of the in-cockpit discourse it can be assumed, that integration of technical English (phraseology) and natural (plain) English, code switching as well as flightdeck panel signs (non-verbal component) may indicate the specialist discourse hybridness.

\section{Hybrid language of in-cockpit communication}

The word 'hybridness' is interpreted by Merriam Webster Dictionary as “... having or produced by a combination of two or more distinct elements...; and... having two different types of components performing essentially the same function". The incockpit communication consists of both technical English (phraseology) and natural (or plain) English - L2 as well as L1 for non-technical communication in monocultural flight crews. In other words, in-cockpit discourse can be defined in terms of a hybrid language, which serves a vehicle of complex human actions to provide language related safety of flights.

Discourse are units primarily concerned with doing things with words, with language as a form of action. A discourse has the verbal and non-verbal components of a complete interactive event. While defining discourse, three definitions have been discussed by researchers - one derived from formalist paradigm, other from functionalist paradigm and the third one that includes both formalist and functionalist paradigms. Within formalist paradigm, the structural analysis of discourse describes 'discourse at several levels or dimensions of analysis and in terms of many different units, categories, schematic patterns or relations' (T. van Dijk 1985: 4). H. Zellig (1951) defines discourse as comprised of 'units'. The functionalist view of discourse analysis asserts that 'the study of discourse is the study of any aspect of language use' (R. Fasold 1990: 65).

In this paper, the implication for professional communication is defined through 'professional' practices. Therefore, the need is for much deeper understanding of context in all its varied forms, including 'studies of how participants undertake the discursive tasks, perform professional actions, and what they achieve through these discursive and professional activities and practices' (V. Bhatia 2012).

Traditionally, the context is defined as the setting and situation in which communication takes place. Context refers to the idea that every act of communication 
must happen in some sort of surroundings. In aviation, most obviously there is the physical context - whether specialists are talking to someone on the work place, in a café, in a boss's room or recreation area. Then there is the social context, which is to do with the occasion involved and the people in it. This might be specialists (e.g., a group of colleagues) or non-specialist (friends, relatives, etc.). And then there is the cultural context, which refers to an even broader set of circumstances and beliefs, which still may affect how the aviation personnel talk.

However, there might be another approach to aviation context in terms of performing flight. Then the in-cockpit discourse context can be described hierarchically in terms of the main context and a few sub-contexts. The main or 'umbrella' context in aviation, and particularly in flight operation, is associated with a strong focus on safety and can be defined as 'safety context'. This context refers to language related human factor as part of techno-human complex system of flight operation and traffic control. Then there are also two other sub-contexts of in-cockpit communication, which refer to verbal and non-verbal stimuli of meaningful utterances produced by coded language, restricted register and according to radiotelephony rules. The verbal context is technically routine (phraseology based) or non-routine (emergency phraseology); techno-human non-routine (based on combination use of phraseology and plain English for radiotelephony purpose); and human interpersonal (based on general spoken English or native language). The non-verbal context of the utterances is highly correlated with the steps (time point) of flight operation and is formed out of three factors: a spatial purview common to pilot and controller (the unity of what is visible - flightdeck panel, controller's monitors); the participants shared common knowledge and understanding of the circumstances, and, finally, their common evaluation of these circumstances.

Therefore, the hybrid language discourse of the cockpit communication can be described (analysed) at multiple dimensions:

- linguistic: use of language as a linguistic act (J. Austin, 1962);

- cognitive: code switching between technical and natural language or between L2 and L1;

- interactional: interaction with multiple receivers in various contexts (communicative intentions context related);

- social: relationships, time of flying together, gender, age.

\section{Method and Materials}

The research results presented in the paper are based on study of discourse known as discourse analysis. The discourse analysis consists of attempts to study the organization of language above the sentence or above the clause, and therefore to study larger linguistic units, such as conversational exchanges or written texts. It follows that it is also concerned with language in use in social contexts, and in particular with interaction or dialogue between speakers (V. Bahrami 1999).

In view of the previous definitions, it should be noted that the main aspects of discourse are act of communication, context, social interaction, and functions and purposes, which underlie the linguistic units above the sentence level. Hence, 
discourse analysis is looked upon as involving both language form and language function and including that part of communication that is unfolded in spoken texts by means of various linguistic devices. On the Fig. 1 below, one can see the cockpit communication pattern presenting variety of settings referred to interactional links, participants of communication in and out the cockpit and the flightdeck panel, which is a non-verbal sign as a stimulus of utterances.

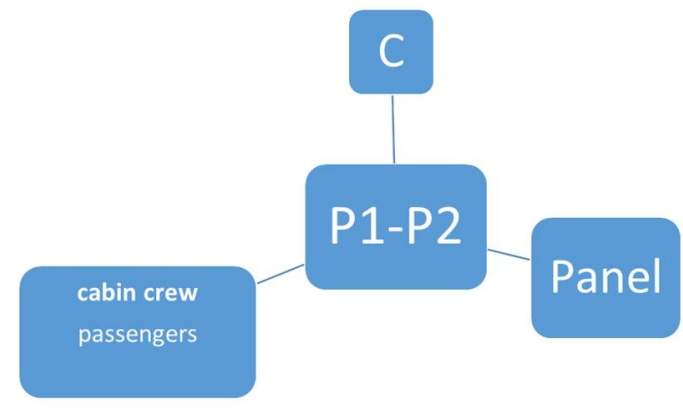

Fig. 1. Pattern/ settings of in-cockpit communication.

The above pattern of in-cockpit communication has been analysed in the case study.

\section{Sample hybrid discourse of cockpit language use}

A case study of in-cockpit communication during the flight operation has suggested a hybrid character of language communication demonstrated by German speaking flight crew. Based on discourse analysis, the hybridness is indicated by high contextuality of the specialist communication in particular settings typical for incockpit communication. Special focus was on specific vectors of interaction defined by human and non-human variables providing different communicative load.

\section{A case study presented by Youtube recording of real world flight operated by Swiss airlines ${ }^{1}$}

For the purposes of the analysis, the language communication in the cockpit has been transcripted with total as of 31 episode of interaction. The blueprint includes parameters referred to the flight stage, utterances produced in the cockpit and comments focusing on kind of language used, communication intent/function, use of non-verbal means of general language interaction, presence of flightdeck panel scanning.

Legend: Swiss airlines flight operated by German speaking flightcrew P1 (pilot flying) - a captain, a male, experienced specialist.

P2 (pilot non-flying) - the first officer (co-pilot), a young female, building up her career.

\footnotetext{
${ }^{1}$ URL https://www.youtube.com/watch?v=hvGoaxgFnsM [Access 30.03.2020].
} 
Purse - a boss of cabin crew, a male.

C - a controller (Ground, Departure).

Languages used: NL2 - general English; TL2 - technical English (including phraseology); L1 - native language (German).

\begin{tabular}{|c|c|c|}
\hline $\begin{array}{l}\text { Flight } \\
\text { stage/episode }\end{array}$ & Utterances produced & $\begin{array}{l}\text { Comments on language } \\
\text { use/communicative intent }\end{array}$ \\
\hline $\begin{array}{l}\text { Before line } \\
\text { up } 1\end{array}$ & P2 to P1: Let's go! & NL2, self-encouraging \\
\hline $\begin{array}{l}\text { Taxiing } \\
2\end{array}$ & $\begin{array}{l}\text { P2: LX64, Request taxi } \\
\text { C: LX64, turn left via link 4, } \\
\text { and taxy ways E and B to } \\
\text { holding position E2. You're all } \\
\text { the way no. } 1 . \\
\text { P2: Link 4, taxy ways E, B, E2, } \\
\text { all the way no. } 1 \text {. }\end{array}$ & $\begin{array}{l}\text { TL2, radiotelephony } \\
\text { routine exchange } \\
\text { Request for taxi; readback } \\
\text { instructions }\end{array}$ \\
\hline 3 & $\begin{array}{l}\text { P1: Left side clear, off we go! } \\
\text { P2: Clear right side. } \\
\text { P1: Thanks. }\end{array}$ & $\begin{array}{l}\text { TL2 in-cockpit exchange } \\
\text { mixed with NL2 } \\
\text { (underlined) } \\
\text { Routine flightdeck check } \\
\text { Politeness }\end{array}$ \\
\hline 4 & P2: Approaching RWY 28 & $\begin{array}{l}\text { TL2, radiotelephony } \\
\text { exchange } \\
\text { Report approaching } \\
\text { Scanning airfield markings }\end{array}$ \\
\hline 5 & $\begin{array}{l}\text { P2: Checked. } \\
\text { P1: Checked. } \\
\text { P1: Not intended call out } \\
\text { [Germ.] } \\
\text { P2: Brake check? } \\
\text { P1: Yeah, let's do that. } \\
\text { P2: Brakes checked. } \\
\text { P2: Pressure } 0 . \\
\text { P2: Radar checked. }\end{array}$ & $\begin{array}{l}\text { TL2, in-cockpit exchange } \\
\text { mixed with NL2+L1 } \\
\text { (underlined) } \\
\text { Routine flightdeck check } \\
\text { Scanning flightdeck panel }\end{array}$ \\
\hline 6 & $\begin{array}{l}\text { C: LX64, standby on tower } \\
\text { frequency } 118.1 \mathrm{MHz} \text {, have a } \\
\text { good day! } \\
\text { P2: 118.1MHz, thanks, you too! } \\
\text { C: Thanks! }\end{array}$ & $\begin{array}{l}\text { TL2, radiotelephony } \\
\text { exchange mixed with NL2 } \\
\text { (underlined) } \\
\text { Provided with new } \\
\text { frequency, readback } \\
\text { Expressing politeness }\end{array}$ \\
\hline 7 & $\begin{array}{l}\text { C: LX85Q, cleared for take off } \\
\text { on RW28. - P: LX85Q }\end{array}$ & $\begin{array}{l}\text { P2 hears another aircraft } \\
\text { instructed on the same } \\
\text { frequency - non-stop }\end{array}$ \\
\hline
\end{tabular}




\begin{tabular}{|c|c|c|}
\hline & $\begin{array}{l}\text { C: LX1961, departure on } \\
\text { RWY28, I call you back shortly. }\end{array}$ & $\begin{array}{l}\text { listening to get the right } \\
\text { message }\end{array}$ \\
\hline 8 & $\begin{array}{l}\text { C: LX64, hello, taxi E1. } \\
\text { P2: E1, LX64 heavy, have a } \\
\text { good day. }\end{array}$ & $\begin{array}{l}\text { TL2, radiotelephony } \\
\text { exchange mixed with NL2 } \\
\text { (underlined) } \\
\text { Expressing politeness }\end{array}$ \\
\hline 9 & $\begin{array}{l}* * \text { Purser to flight crew: Cabin } \\
\text { and galley are secured. }-P 1: \\
\text { Thanks. }\end{array}$ & $\begin{array}{l}\text { L1Germ+French, using } \\
\text { eye contact, purser's } \\
\text { thumb up, smiling. } \\
\text { Cabin crew report }\end{array}$ \\
\hline 10 & $\begin{array}{l}\text {... } \\
\text { P2: That's copied, LX64. Our } \\
\text { departure time is at minute } 51 \text {. }\end{array}$ & $\begin{array}{l}\text { TL2, radiotelephony } \\
\text { exchange } \\
\text { Readback departure time }\end{array}$ \\
\hline 11 & $\begin{array}{l}\text { P2: TO/GA take off, decision } \\
\text { speed } 153 \mathrm{kt} \text {. } \\
\text { P1: } \text { Sounds about right }\lceil\text { Germ.] } \\
\text { P2: Rotation at } 154 \mathrm{kt} \text {. Fly speed } \\
\text { 158 kt. Stop margin } 252 \mathrm{~m} . \\
\text { Cleaned } 247 \mathrm{~m} . \\
\text { P1: Assumed temperature?' } \\
\text { P2: Full thrust take off! TO/GA } \\
\text { take off. } \\
\text { P1: Really? TO/GA? [O-oh! } \\
\text { Laughs] } \\
\text { P2: I'm ready. }\end{array}$ & $\begin{array}{l}\text { TL2, in-cockpit exchange } \\
\text { mixed with NL2+L1 } \\
\text { (underlined) } \\
\text { Routine flightdeck check } \\
\text { Scanning flightdeck panel }\end{array}$ \\
\hline 12 & $\begin{array}{l}\text { C: Edelweiss (EDW) } 4 \mathrm{~K} \text { now I } \\
\text { think your radio is fine again. } \\
\text { Continue taxi H, B, holding } \\
\text { position B2. } \\
\text { P: H, B, B2, EDW4K heavy }\end{array}$ & $\begin{array}{l}\text { P2 hears another aircraft } \\
\text { instructed on the same } \\
\text { frequency - non-stop } \\
\text { listening to get the right } \\
\text { message }\end{array}$ \\
\hline 13 & $\begin{array}{l}\text { P1: It's flying weather today! } \\
\text { [Germ. }] \\
\text { P2: Perfect! [Eye contact, smile] } \\
\text { P1: Imagine we'd witness Swiss } \\
\text { monsoon! [Germ.] } \\
\text { P2: In any case, it will be nicer in } \\
\text { Miami. 32 Co [Germ.] } \\
\text { P2: Runway 16 (Holding point), } \\
\text { E1. } \\
\text { P2: Cabin is ready. } \\
\text { P1: Before takeoff checklist. } \\
\text { P1: Flight controls. } \\
\text { P2: Checked.- P1: Checked. }\end{array}$ & $\begin{array}{l}\text { TL2, in-cockpit exchange } \\
\text { mixed with NL2+L1 } \\
\text { (underlined) } \\
\text { Eye contact, smiling } \\
\text { Maintaining dialogue due } \\
\text { to comfort crewmembers } \\
\text { relationships } \\
\text { Routine flightdeck check } \\
\text { Scanning flightdeck panel }\end{array}$ \\
\hline
\end{tabular}




\begin{tabular}{|c|c|c|}
\hline 14 & $\begin{array}{l}\text { C: LX64, expect departure in } 7 \\
\text { min. }\end{array}$ & $\begin{array}{l}\text { TL2, phraseology, } \\
\text { controller's information } \\
\text { Departure time } \\
\text { confirming }\end{array}$ \\
\hline 15 & $\begin{array}{l}\text { P2: Flaps } 2 . \\
\text { P2: Take off speeds - new - } \\
\text { 153kt. } \\
\text { P2, P1: 153, 154, } 158 \mathrm{kt} . \\
\text { \{pronounce together\} } \\
\text { P1: Full thrust takeoff. (TO/GA) } \\
\text { P2: TO/GA take off. -P1: } \\
\text { Checked. } \\
\text { P2: ECAM memo. - P1: Checked. } \\
\text { P2: Checked down to the line } \\
\text { complete. } \\
\text { P1: ECAM memo, take off no } \\
\text { blue. } \\
\text { P1: Let's have a last review. } \\
\text { [Germ.] I've got some time. } \\
\text { \{verifying with data in Tablet\} } \\
\text { P2: We have tailwind 6kn and } \\
\text { QNH 1024 hPa. } \\
\text { P1: Are we moving? [Germ.] No! } \\
\text { \{continue verifying with Tablet\}. } \\
\text { P1: Quick word to the } \\
\text { passengers. }\end{array}$ & $\begin{array}{l}\text { TL2, in-cockpit exchange } \\
\text { mixed with NL2+L1 } \\
\text { (underlined) } \\
\text { Routine flightdeck check } \\
\text { Scanning flightdeck panel }\end{array}$ \\
\hline 16 & $\begin{array}{l}\text { C: Cleared to cross RWY28, } \\
121,750 \mathrm{MHz} \text {, bye-bye, LX98A }\end{array}$ & $\begin{array}{l}\text { P2 hears another aircraft } \\
\text { instructed on the same } \\
\text { frequency - non-stop } \\
\text { listening to get the right } \\
\text { message }\end{array}$ \\
\hline 17 & $\begin{array}{l}\text { C: LX64, Tower, hello, line up } \\
\text { RWY16 report ready, } \\
\text { departure in } 5 \text { minutes. } \\
\text { P2: Line up and wait. TWY 16, } \\
\text { LX64. }\end{array}$ & $\begin{array}{l}\text { TL2, radiotelephony } \\
\text { exchange } \\
\text { Readback line up }\end{array}$ \\
\hline 18 & $\begin{array}{l}\text { Pl to passengers (via telecom) - } \\
\text {...we just received our line up } \\
\text { clearance, so expect our } \\
\text { departure in the next two } \\
\text { minutes. We wish you a very } \\
\text { pleasant flight! }\end{array}$ & $\begin{array}{l}\text { NL2, routine welcome } \\
\text { speech (out-of-cockpit } \\
\text { addressee) }\end{array}$ \\
\hline
\end{tabular}




\begin{tabular}{|c|c|c|}
\hline 19 & 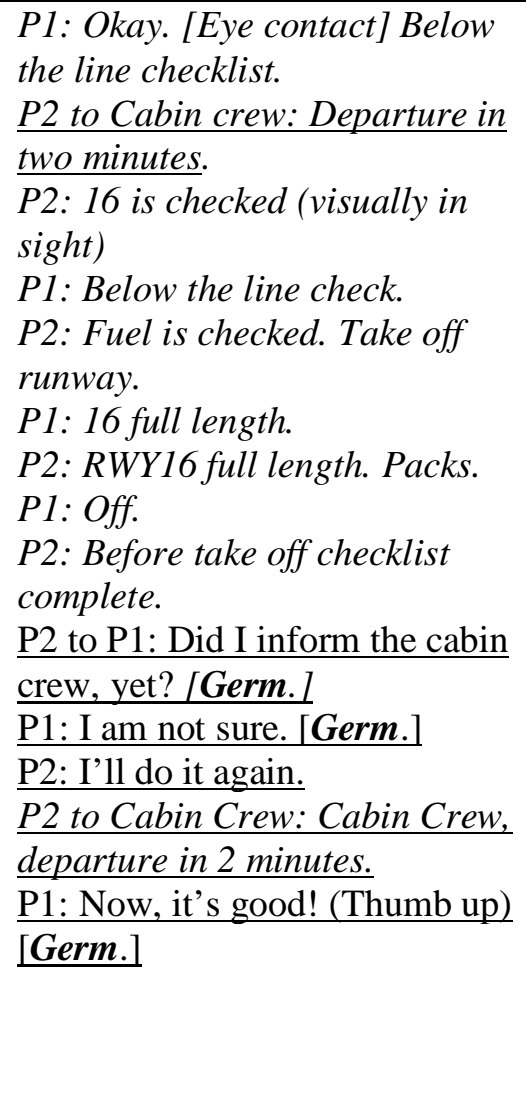 & $\begin{array}{l}\text { TL2, in-cockpit exchange } \\
\text { mixed with NL2+L1 } \\
\text { (underlined) } \\
\text { Scanning airfield markings } \\
\text { P2 is nforming cabin crew } \\
\text { (routine procedure, out-of- } \\
\text { cockpit addressee) } \\
\text { Routine flightdeck check } \\
\text { Scanning flightdeck panel } \\
\text { P2 repeatedly inform cabin } \\
\text { crew. } \\
\text { Asking the captain in L1 } \\
\text { (a bit nervous of not } \\
\text { remembering important } \\
\text { action done) } \\
\text { Captain encouraged the } \\
\text { first officer by words } \\
\text { (verbally) and gesture } \\
\text { (non-verbally) }\end{array}$ \\
\hline 20 & $\begin{array}{l}\text { C: LX188 behind the Thai B777, } \\
\text { line up RWY16 and wait. } \\
\text { P: Lining up behind the B777, } \\
\text { LX188. }\end{array}$ & $\begin{array}{l}\text { P2 hears another aircraft } \\
\text { instructed on the same } \\
\text { frequency - non-stop } \\
\text { listening to get the right } \\
\text { message }\end{array}$ \\
\hline 21 & $\begin{array}{l}\text { P1: You are ready, right? } \\
\text { Germ. }] \\
\text { P2: I'm ready. }\end{array}$ & $\begin{array}{l}\text { Repeatedly confirm } \\
\text { readiness to take off }\end{array}$ \\
\hline 22 & $\begin{array}{l}\text { C: THA971 behind the Swiss } \\
\text { Airbus } 330 \text {, line up RWY } 16 \text { and } \\
\text { wait. } \\
\text { P: Behind the A330 line up and } \\
\text { wait, THA971. }\end{array}$ & $\begin{array}{l}\text { P2 hears another aircraft } \\
\text { instructed on the same } \\
\text { frequency - non-stop } \\
\text { listening to get the right } \\
\text { message } \\
\text { Scanning flightdeck panel }\end{array}$ \\
\hline $\begin{array}{l}23 \\
\text { Autopilot } \\
\text { sign and } \\
\text { sound: }\end{array}$ & $\begin{array}{l}\text { P2: Checked. Heading checked. } \\
\text { P2: TO/GA take off. Off we go! }\end{array}$ & $\begin{array}{l}\text { TL2, in-cockpit exchange, } \\
\text { mixed with NL2 } \\
\text { Routine flightdeck check } \\
\text { Scanning flightdeck panel }\end{array}$ \\
\hline
\end{tabular}




\begin{tabular}{|c|c|c|}
\hline $\begin{array}{l}\langle\text { On } \\
\text { runway 16 }>\end{array}$ & & $\begin{array}{l}\text { (waiting to hear take off } \\
\text { clearance) }\end{array}$ \\
\hline 24 & $\begin{array}{l}\text { C: LH9C, contact departure, bye! } \\
\text { P: Contacting departure control, } \\
\text { bye! }\end{array}$ & $\begin{array}{l}\text { P2 hears another aircraft } \\
\text { instructed on the same } \\
\text { frequency - non-stop } \\
\text { listening to get the right } \\
\text { message }\end{array}$ \\
\hline $\begin{array}{l}\text { Take off } \\
\text { clearance } \\
\text { heard } \\
25\end{array}$ & $\begin{array}{l}\text { C: LX64, wind } 180^{\circ}, 6 \mathrm{kt} \\
\text { runway } 16 \text {, cleared for take off. } \\
\text { P: Cleared for take off RWY16, } \\
\text { LX64. }\end{array}$ & $\begin{array}{l}\text { TL2, radiotelephony } \\
\text { exchange } \\
\text { Readback cleared for take } \\
\text { off } \\
\text { Scanning flightdeck panel }\end{array}$ \\
\hline $\begin{array}{l}\text { Taking off } \\
\text { Airborne } \\
26\end{array}$ & $\begin{array}{l}\text { P2: Wind is OK. } \\
\text { P1: Fuel time, take off. } \\
\text { P1: Manual TO/GA SRS, Runway } \\
\text { auto-thrust (A/THR) blue. } \\
\text { P2: Checked. [monitoring } \\
\text { readings changes active on the } \\
\text { panel] } \\
\text { P2: Thrust set. } \\
\text { P2: Speed } 100 \text { knots. } \\
\text { P1: Checked. } \\
P 2: \text { Rotate. [taking off, airborne] } \\
P 2: \text { Positive climb. } \\
\text { P1: Gear up! } \\
\text { P2: Gear up. }\end{array}$ & $\begin{array}{l}\text { TL2, in-cockpit exchange } \\
\text { Routine flightdeck check } \\
\text { Scanning flightdeck panel }\end{array}$ \\
\hline $\begin{array}{l}\text { Switching to } \\
\text { Dparture } \\
\text { frequency } \\
27\end{array}$ & $\begin{array}{l}\text { C: LX64, contact departure } \\
\text { and enjoy Miami! } \\
\text { P: Contacting departure, LX64 } \\
\text { P: Departure, hello, LX64 } \\
\text { heavy, } 2700 \text { ft climbing to } 5000 \\
\text { ft. } \\
\text { C: Departure radar identified, } \\
\text { climb to } 6000 \mathrm{ft} \text {. } \\
\text { P: Climb to } 6000 \mathrm{ft}, \mathrm{LX64.}\end{array}$ & $\begin{array}{l}\text { TL2, radiotelephony } \\
\text { exchange } \\
\text { Readback new contact } \\
\text { Report climbing Readback } \\
\text { new climbing instruction } \\
\text { Scanning flightdeck panel }\end{array}$ \\
\hline $\begin{array}{l}\text { Intitial } \\
\text { Climb } \\
28\end{array}$ & $\begin{array}{l}\text { P1: } 6000 \text { ft blue. - P2: Checked. } \\
\text { P1: Thrust climb. - P2: Checked. } \\
\text { P1: NAV is checked. - P2: } \\
\text { Checked. } \\
\text { P1: Derated climb 2.(climb } \\
\text { thrust) } \\
\text { P2: Checked. }\end{array}$ & $\begin{array}{l}\text { TL2, in-cockpit exchange } \\
\text { Routine flightdeck check } \\
\text { Scanning flightdeck panel }\end{array}$ \\
\hline
\end{tabular}




\begin{tabular}{|l|l|l|}
\hline & $\begin{array}{l}\text { P1: } 4000 \text { ft north of KLOTEN. - } \\
\text { P2: Is checked. }\end{array}$ & \\
\hline Climbing & $\begin{array}{l}\text { P1 to P2 [pointing through the } \\
\text { windshield]: Look down there. } \\
\text { The Thai (another aircraft) from } \\
\text { behind us. }\end{array}$ & $\begin{array}{l}\text { NL2 remark on position of } \\
\text { another aircraft in sight, } \\
\text { gesture (non-verbal) }\end{array}$ \\
\hline Climbing & $\begin{array}{l}\text { C: LX64, climb FL87. } \\
\text { P: Climb flight level, LX64. }\end{array}$ & $\begin{array}{l}\text { TL2, radiotelephony } \\
\text { exchange } \\
\text { Readback new climbing } \\
\text { instruction } \\
\text { Scanning flightdeck panel }\end{array}$ \\
\hline End of climb & $\begin{array}{l}\text { P1: } 8000 \text { ft blue. }- \text { P2: Checked. } \\
\text { P1: Climb. - P2: Checked. } \\
\text { P1: Flaps 1. - P2: Speed } \\
\text { checked. }\end{array}$ & $\begin{array}{l}\text { TL2, in-cockpit exchange } \\
\text { Routine flightdeck check } \\
\text { Scanning flightdeck panel }\end{array}$ \\
\hline
\end{tabular}

Table 1. A case study presented by Youtube recording of real world flight operated by Swiss airlines.

\section{Results and Discussion}

The case study showed the complex nature of language hybridness of in-cockpit specialist discourse due to both technical and natural English use as L2, codeswitching between phraseology and plain English, code switching between technical and natural L2 and between natural L2 and natural L1, processing verbal-visual integrative messages, high communicative load due to non-stop monitoring of radiotelephony frequency. Also, language use was found to vary as a function of crew position and level of workload during the flight.

Quantitatively it has been revealed that 171 word was uttered in TL2 in a setting of radiotelephony flight crew interaction with ground control (11 episodes), 189 words appeared in TL2 flightdeck exchanges in 10 episodes, 46 words were uttered in NL2 and 11 utterances produced in German (L1) in interaction between crewmembers $(3+6$ episodes correspondingly). It was noticed, that L1 was used mostly by captain. He also was an initiator of L1 utterances in most of episodes. In general, the captain (P1) behaved more relaxed, using more natural language in interaction, including welcome speech for passengers.

The flightdeck panel scanning took place in all episodes related to TL2 use. This fact confirms the assumption of technical non-verbal component visualization as a stimulus for language utterances with particular meaning, mainly routine in the given case.

The case study showed that only about a half of the in-cockpit oral discourse was based on radiotelephony exchanges and another half - on crewmembers' exchanges, in both settings TL2 was used with occasional switching on NL2. Part of the discourse refered to out-of-cockpit participants - cabincrew and passengers. A few utterances 
refered to personal relationship between crewmembers mainly with functions of politeness and encouraging.

The analysis of the case study has initially revealed some specific characteristics of the specialist discourse created at a given time period of a routine flight operation (from taxi to end of climb) and in a variety of interactional settings (radiotelephony exchange with control, in-cockpit exchanges between crewmembers, interaction with a cabin crew, talking to passengers). Each setting refers to particular communication intents. The intents then provide the use of a particular language (Table 2).

\begin{tabular}{|l|l|l|l|}
\hline \multicolumn{4}{|c|}{ Discourse profile } \\
\hline $\begin{array}{l}\text { Interactional } \\
\text { settings }\end{array}$ & $\begin{array}{l}\text { Communication } \\
\text { intent/function }\end{array}$ & Language used & $\begin{array}{l}\text { Panel readings } \\
\text { link }\end{array}$ \\
\hline $\begin{array}{l}\text { Radiotelephony } \\
\text { exchange with } \\
\text { control }\end{array}$ & $\begin{array}{l}\text { To request } \\
\text { To report } \\
\text { To readback } \\
\text { (repeat) }\end{array}$ & $\begin{array}{l}\text { Technical } \\
\text { English } \\
\text { (phraseology, } \\
\text { plain English) }\end{array}$ & moderate \\
\hline $\begin{array}{l}\text { In-cockpit } \\
\text { exchanges } \\
\text { between } \\
\text { crewmembers }\end{array}$ & $\begin{array}{l}\text { To inform } \\
\text { To verify } \\
\text { To confirm }\end{array}$ & $\begin{array}{l}\text { Technical } \\
\text { English } \\
\text { (flightdeck } \\
\text { terminology, } \\
\text { phraseology, } \\
\text { plain English) }\end{array}$ & strong \\
\hline $\begin{array}{l}\text { Interaction } \\
\text { with a cabin } \\
\text { crew }\end{array}$ & To inform & $\begin{array}{l}\text { Plain English } \\
\text { language }\end{array}$ & light \\
\hline $\begin{array}{l}\text { Talking to } \\
\text { passengers }\end{array}$ & $\begin{array}{l}\text { To welcome } \\
\text { To inform }\end{array}$ & $\begin{array}{l}\text { General } \\
\text { English }\end{array}$ & no \\
\hline
\end{tabular}

Table 2. Hybrid specialist discourse of in-cockpit language communication.

\section{Conclusion}

In the modern globalized world, the language communication seems to be a challenge. It is getting more complex alongside dynamic growth of globalizing access to any interlocutor. Therefore, linguistic studies focus on its discursivity, contextually multilingual and multicultural nature of most interactions. Regarding the aforementioned shift of paradigm in recent linguistic studies, it is obvious to have a new look at cockpit language communication during the flight performance.

The conceptual background for the in-cockpit communication study is the actionoriented approach to specialist communication providing discursive shift.

The hybrid language use in the cockpit creates the oral language discourse. The former can be defined as a mixture of terms (phraseology) and non-terms (plain language) equally used in a professional communication between flight crews and 
controllers for transmitting specialist messages. The in-cockpit communication study showed the dynamic and developing linguistic repertoire of each individual crewmember. The communicative load is more on the pilot not flying (P2) due to the need to interact simultaneously in three communication settings (interaction with a controller, P1, cabin crew) switching on/off between technical and natural language. In addition to speaking in the three settings, the pilot not flying is significantly loaded with flightdeck scanning and with non-stop frequency monitoring. The four main conclusions can be as follows:

1. use of different languages for one common purpose - safe flight operation;

2. crewmember's interaction aimed at both job related tasks and interpersonal communication;

3. regular code switching between L2 and L1 and between TL2 and NL2;

4. scanning the readings from the flightdeck panel simultaneously with producing utterances in TL2/NL2.

\section{References}

Austin, J.L. (1962), How to Do Things with Words. Oxford.

Bahrami, A. (1999), A Dictionary of Discourse Analysis. Rahnama Publication.

Bhatia, V. (2012), Critical reflections on genre analysis, (in:) "Ibérica" 12, 17-28

(URL http://www.aelfe.org/documents/03_24_Bhatia.pdf). [Access 30.03.2020].

Dijk, T. van (1985), Handbook of Discourse Analysis. London.

Doc 9835 AN/453. (2010), Manual on the Implementation of ICAO Language Proficiency Requirements. ICAO publication.

Fasold, R. (1990), The sociolinguistics of language. Oxford.

Lopez, S./ A. Condamines/ A. Josselin-Leray et al. (2015), Linguistic Analysis of English Phraseology and Plain Language in Air-Ground Communication, (in:) "Journal of Air Transport Studies", 4(1), 44-60.

Mell, J./ C. Godmet (2002), Communication functions in language for aviation ratiotelephony, (in:) J. Mell/ C. Godmet (eds.), Direction de la Navigation Aerienne: DNA8 (F).

Petrashchuk, O. (2017), Aviation Radiotelephony discourse: an issue of safety, (in:) M. Grygiel (ed.), Cognitive Approaches to Specialist Languages. Cambridge, 114-134.

Zellig, H. (1951), Methods in Structural Linguistics. Chicago. 